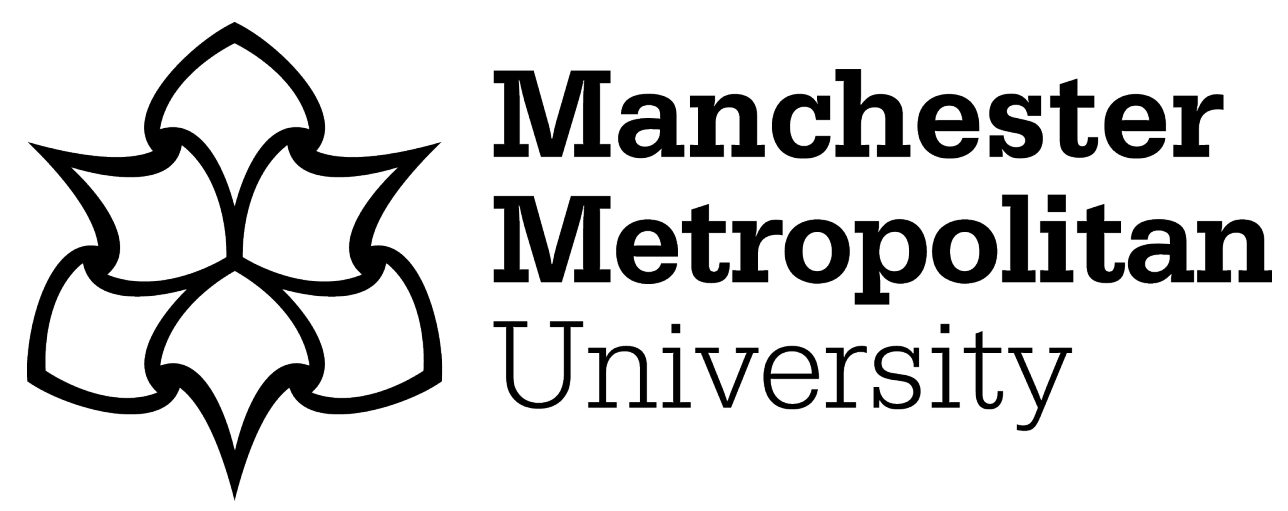

Bailey, Daniel (2017) Economic renewal through devolution? Tax reform and the uneven geographies of the economic dividend. Competition \& Change, 21 (1). pp. 10-26. ISSN 1024-5294

Downloaded from: https://e-space.mmu.ac.uk/623406/

Version: Accepted Version

Publisher: SAGE Publications

DOI: https://doi.org/10.1177/1024529416678069

Please cite the published version 


\title{
Economic renewal through devolution? Tax Reform and the uneven geographies of the economic dividend
}

\author{
Dr. Daniel Bailey \\ Sheffield Political Economy Research Institute (SPERI) and the University of York
}

\begin{abstract}
The economic governance of the UK is currently in flux with various devolution agreements being negotiated across the country. This article examines the changing political economy of the UK enforced by Wave 1 City Deals, to analyse the claims made by devolution proponents that there is an 'economic dividend' to devolution. The argument is made that scant evidence exists to suggest that these reforms respond to the deep-seated pathologies of the UK economy. Instead, the Northern powerhouse discourse serves to disguise the implementation of a tax and investment settlement which regressively concentrates taxation revenue in the more affluent parts of the country. These reforms though are a political expression of a certain understanding of wealth creation which privileges low tax taxation, inter-territorial competition to promote it and a belief in the major UK cities to drive the economic recovery. It is a strategy likely to produce very uneven geographies of growth which will exacerbate uneven development; ironically so given the 'Northern Powerhouse' rhetoric through which it was reasoned.
\end{abstract}

\section{Introduction}

The recent political and economic focus on city-regions, as the spatial scale at wealth creation is driven (Florida, 2002; Glaeser, 2011), has informed the formulation of the English devolution agreements (Williams et al., 2016). The Coalition Government's devolution of particular powers to England's largest cities and their re-shaping of the financing arrangements of local 
government form two key components of the 'Northern Powerhouse' agenda ${ }^{1}$. The recomposition of the tax settlement is designed to localise the income of business rates in the local area and promote competition between sub-national polities on rates, in order to 'incentivise' and 'reward' growth (Osborne, 2015a). The Coalition Government claimed that these reforms would equip cities with the financial tools and incentives they needed to deliver change and tackle the UK's deep-seated uneven development. These devolution agreements constitute a re-structuring of the constitutional and fiscal conditions through which strategic governmental outcomes are achieved and consequently it is important to analyse the long-term political and economic repercussions for the UK.

Devolution's presumed ability to promote economic growth (Lyall et al., 2015; Tomaney, 2016) has invoked scholarly debates on the empirical relationship between fiscal decentralisation and growth. Contemporary proponents of English devolution hypothesise the relationship to be a strong and positive one, with Michael Heseltine's recent report - 'No Stone Unturned' - playing an influential role in conflating the two. However, this research engages with the literature which posits that the relationship between growth and devolution is a more complex one than proponents wish to acknowledge (Rodriguez-Pose and Gill, 2005; Jeffery 2006; Pike et al., 2010), and the tendencies of these reforms to have little effect or a negative effect on uneven development (Baskaran and Feld, 2009; Pike and Tomaney, 2009; Rodriguez-Pose and Ezcurra, 2010). This paper will tackle the question of whether the relationship between devolution and growth is as simple and positive as purported by advocates of the Northern powerhouse and the character and uneven geographies of the economic growth likely to be produced by these reforms. Firstly, it will question whether the 'diagnosis' of over-centralised economic governance adequately addresses the conventional 'pathologies' of the UK's relatively idiosyncratic growth model; centred conventionally on asset bubbles in the South East, escalating private indebtedness and a deregulated financial sector (Crouch, 2009; Hay, 2013). Secondly, I will analyse the distributory reforms to governmental resources enacted by the changes to business rate taxation and 'Earn Back' arrangements in order to analyse the geographic unevenness of the growth. I will argue that the specific reconfiguration of economic governance, and the ideas they are informed by, is set to funnel additional resources into existing sub-national growth hubs in a way which exacerbates uneven development rather than ameliorates it. This article will, thus, bring together disparate bodies of knowledge and information to critically scrutinise the claims of an economic dividend to English devolution, which, it is purported will instigate an economic 're-balancing'.

In order to shed some light on these matters, I shall proceed as follows. At the outset, I will examine the economic hubris of the devolution advocacy and how it relates to the academic literature on whether devolution brings with it an 'economic dividend'. The validity of these economic claims will be assessed by examining the disconnect with the modest selection of policies actually being devolved and contextualising them within the conventional pathologies of the UK economy's 'growth model' and its deep-seated history of uneven development. Thereafter, the localisation of tax income and assess its implications for the poorer areas of the country who are running 'budget deficits' with Central Government is examined. The

${ }^{1}$ This article will focus simply on Wave 1 City Deals as well as the re-moulding of the fiscal conditions facing these cities. 
implications of devolution in terms of the re-appropriation of the 'dependency culture' idea to describe regions benefitting from redistribution is discussed. Finally the abolition of universal business rates and its potential to instigate a 'race to the bottom' is examined and the likely winners and losers of inaugurating such a framework of sub-national competition identified. The conclusion reflects on what these reforms mean for uneven development in the UK and the variegated relationship between devolution and economic growth in this particular context.

\section{The hubris of the devolution debate}

The most recent attempts to decentralise power in the UK have been embraced by actors from across the political spectrum in the UK, from think tanks as disparate as Republica and IPPR North and among political elites in Central Government and Local Government alike. The advocacy of the devolution agenda has featured numerous rationales, but none have been more central than the promise that devolution will bring with it an 'economic dividend'.

A New Economics Foundation (NEF) research project which sought to demystify and rigorously map out the devolution advocacy - its anticipated outcomes and the imagery invoked - demonstrated that economic arguments have dominated the recent devolution debate (Lyall, Wood and Bailey, 2015). The report illustrated that claims of a relationship between devolution and economic growth constituted 41.6 per cent of the advocacy discourse (and 52.5 per cent of the arguments made in documents produced by Local Government and Local Enterprise Partnerships), and the expectation that the 'devolution revolution' would generate an inclusive form of growth covering the regions outside of London (Lyall et al., 2015).

\section{[ENTER FIGURE 1 HERE]}

Source: Lyall, Wood and Bailey (2015)

Such a discourse appears to be informed by the evidence which suggests that urban areas today serve as the engines of wealth creation and job growth, and have been lionised as such by a variety of influential authors and think tanks (Florida, 2002; Glaeser, 2011; Katz and Bradley, 2014; Centre for Cities, 2015a). Michael Heseltine's oft-cited report 'No Stone Unturned' gave political traction to the idea that devolving powers could help generate an economic recovery, and he set the tone for the argument that the engines of national growth require emancipation from the claws of state intervention and regulation (Heseltine, 2012). In the context of a slow and geographically uneven economic recovery and long-standing regional inequalities within the UK, opinion coalesced around the need for change of some form. These ideas increasingly fed into the Coalition Government's Cities and Local Growth agendas through Parliament; with the notion of localism, decentralisation and the Northern Powerhouse coming to replace the prior state-centric focus on economic re-balancing (Hildreth and Bailey, 2013; Tomaney, 2016). 
Yet, that the Wave 1 City Deals will act as a panacea for low growth and uneven development remains an article of faith amongst its purveyors. As the NEF report showed, a disaggregation of the economic growth arguments showed that examination of this relationship (devolution may produce increased investment opportunities or will utilise local knowledge to tackle local problems, for example) were less common that the arguments which simply sought to depict the relationship as commonsensical. Therefore, the question of how devolution will lead to growth and where it is most likely to do so is largely without clarification in mainstream political discourse.

This is typical of devolution advocacy more broadly (Rodriguez-Pose and Sandall, 2008), but despite the hyperbole of the devolution advocacy - the body of scholarship on the 'economic dividend' debate reveals social and geographic variegations. As numerous scholars have stated, no a priori assertions can be made on the subject as numerous other variables - such as institutional context and the form of devolution being pursued - play significant roles in determining the relationship between devolution and growth (Ashcroft et al. 2005; McGregor and Swales 2005; Rodriguez-Pose and Gill, 2005 ). Jeffery (2006) in his 6-year ESRC-funded study on the Devolution and Constitutional Change found little evidence to support the economic dividend hypothesis, but did state that there was "much to suggest that devolution... even administrative devolution... will lead to a widening of regional economic disparities" and that there was only a limited governmental capacity to intervene to address economic imbalances (Jeffery 2006: 1). Pike and Tomaney (2009) follow suit by making that the case that previous attempts to address uneven development in the UK through devolution have led to fragmentation and incoherence in a way which has been damaging to territorial equity. Pike et al. (2010) meanwhile argue that it is difficult to discern any evidence for the hypothesis, but add that where evidence of a boost in economic performance can be identified, a disaggregation of the evidence reveals it to be limited to very specific spatial zones. They believe that the political primacy of national growth strategies shapes regional imbalances through privileging or peripheralising certain industries or regions; a point which emphasises the continued importance of central government policy-making rather than local agency even within a devolved political system.

\section{City Deals as a response to macroeconomic failings}

The body of scholarship on the 'economic dividend' of devolution, therefore, offers ambiguous evidence to those attempting to forecast the macroeconomic consequences of City Deals in the UK. The hubristic devolution discourse which prophesises that the new agreements will produce a new wave of growth across the 'Northern Powerhouse' and reduce geographical inequalities ought to be tempered by three key points.

Firstly, it is worth pointing out that underneath the hubris of the devolution advocacy, an analysis of the City Deal agreements reveal that only a relatively modest selection of powers are being transferred to the local level. Significantly, the powers which have been devolved typically in the area of transport, skills and strategic planning - also tend to correspond to the pre-existing objectives of the Treasury; reflecting a wish for Treasury objectives to be met by 
local authorities. Negotiations between local elites and representatives from Whitehall (led by the Treasury Minister in the House of Lords and former Goldman Sachs Chief Economist, Jim O'Neill) have been shaped by the language of the Treasury and the eagerness of local actors who are keen to make the case that they are best positioned and trustworthy enough to deliver these top-down Treasury objectives (Lee, 2015). Therefore, what we have seen so far is a 'central control, local delivery' model of devolution (Bailey, 2015), rather than a radical re-imagining of the UK's economy's shape or strategy. Or, to put it another way, an example of what Maclennen and O'Sullivan (2013) describe as 'policy dumping'; the transfer of formal but not effective policy responsibility. The budgets devolved will now be wielded by local actors but only to secure the objectives shaped by Central Government. Indeed, it can be said to constitute the covert shoring up of central control through the co-option of local elites (Smith and Richards, 2015).

The City Deals do of course create new budgets for local areas designed to stimulate growth through infrastructure and skills expenditure. This endowment of funds, however, must be located within the context of austerity measures, which mean that generally across the North of England, available funding is shrinking. Taking these two in combination, it appears as though Central Government is enacting a re-moulding of local spending through added conditionality. As a result of these reforms, councils will have less to spend on social programmes and an increasing amount earmarked for specific economic and infrastructure projects. This emphasises the paradoxical centralisation which is taking place as part of these devolution deals, with the influence of Treasury objectives being strengthened through conditionality.

To underline the extent to which Central Government retain control over this process, the powers which have been bequeathed to local government could also be rescinded (to far less fanfare one would imagine) if future 'performance evaluations' deem that they have been used inappropriately (Smith and Richards, 2015). A largely overlooked insertion into the 'Devo Manc' agreement states that "the next five year tranche of funding will be unlocked if HMT is satisfied that the independent assessment shows the investment to have met the objectives and contributed to national growth" (HM Treasury and GMCA 2015: 5); setting a precedent for future devolution agreements. The government may wish to depict their new role as an armslength governance of autonomous fiefdoms, but actually the extent to which the centre retains control is dramatically underplayed by Central and Local Government alike.

There may well be some minor benefits of certain functions being wielded by those with a greater knowledge of local shortcomings, but this is certainly no 'revolution' in UK economic governance which empowers Northern communities to address the long-standing issues of the manufacturing industry in the North or implement a more decisive industrial policy. In fact, many of the new services boasted about in the City Deal agreements replicate the deep-seated practice of British industrial policy to focus on micro-level interventions, the dissemination of 'best-practice' through policy learning, and 'soft support' in the form of advice services (Buigues and Sekkat, 2009).

The point being made here is not that a larger transferral of powers to the local level would 'naturally' have produced accelerated growth. Rather it is argued that, despite the devolution hubris, what we are witnessing is a minor technocratic recalibration of economic governance and, 
thus, a largely 'business-as-usual' approach to economic management. Accordingly, it is difficult to ascertain exactly why there such confidence that a broadly business-as-usual approach to economic management will produce an unusually higher growth rate.

Secondly, it cannot be overlooked that these reforms are taking place in the context of austerity. The confidence that devolution will produce a wave of growth in the North is difficult to reconcile with the knowledge that austerity measures - and it is prudent to remind ourselves that the less affluent areas of the North have been hit disproportionately by austerity (Berry and White, 2014) - will continue to be . Local authorities and City Mayors who have been tasked with these objectives will surely find the allocation of some budgets pitiful compensation for the retrenchment of overall local expenditure as they try to generate economic expansion.

The overall local government grant shrunk by 37 per cent in real-terms between 2010 and 2015, and is expected to fall further over the course of the current parliament (NAO, 2015). These cuts constitute a larger barrier to growth in more deprived areas due to the uneven distribution of austerity measures - equating to $£ 228$ per person in the 10 per cent of most deprived of local authorities since 2010, compared to $\AA^{44}$ per person in the 10 per cent of most affluent local authorities (Berry and White, 2014).

Indeed, there have been suggestions that the devolution agenda is being partly driven by a desire from certain actors in Central Government to 'shift the blame' for anaemic growth and austerity. Aided by the obfuscation of accountability enabled by the patchwork of bespoke City Deals being negotiated and the widespread lack of understanding in the North of the powers being devolved (Ipsos Mori, 2015), devolution means that responsibility for unpopular austerity measures and the perennially stagnant economic zones of the North are being blurred.

Thirdly, the question is raised as to the extent that City Deals actually address the evident economic ills of the UK economy. The common pathologies of the UK economy put forward since the crash of 2008 - put forward by people like Colin Crouch (2009) and Colin Hay (2013) - have tended to emphasise a relatively idiosyncratic and dysfunctional 'growth model' in which domestic demand was supported by a deregulated and highly-leveraged financial sector, an influx of capital from Asia (primarily China), escalating private indebtedness, asset bubbles in the South East (particularly the housing market), and a dependence on the continuation of low interest rates. This growth model enables an understanding of why the crash occurred and proliferated in the way it did in 2008, and the pro-cyclical dynamics which have hindered the UK's economic recovery to date. The UK's economic recovery has been built on these familiar dynamics since 2013, and politicians have failed to 'rebalance' the economy away from the finance sector and the South East (Berry, 2013; Berry and Hay, 2014; Meadway, 2015).

The proponents of devolution claim that it is the key to 'unlocking growth' (Core Cities, 2013), but to what extent does this reconfiguration of governance address the frailties of the current growth model or the need to construct a more sustainable economic model? Since the discourse on 'economic re-balancing' (and the opaque set of policies it was associated with) faded away, the devolution agenda has represented the most discursively prominent governmental response to uneven development. However, it does appear as if the claim this presumed relationship between devolution and growth has taken no heed of any diagnosis of the UK economy's ills to date. 
City deals do not represent a coherent economic strategy. Their ad-hoc, asymmetrical, patchwork approach is highly unlikely to lay foundations for any alternative economic strategy which addresses the failings of the existing economic system. Consequently, there is little to substantiate the claim that "devolution is one of the necessary conditions for the economic renewal of Britain's cities and regions, especially those that lie outside the charmed circle of London and the South East. Devolution would and will allow for several changes which could, and we believe will, shift the economic growth prospects of our cities and regions by several orders of magnitude" (Blond and Morrin, 2015: 6). Devolution, and these City Deals more specifically, do little to address the manifest socio-economic failings or uneven geographies of the UK economy. It remains unclear exactly how exactly devolution will unleash a wave of economic expansion powerful enough to offset austerity measures, or how that growth will conform to a more sustainable and equitable macroeconomic strategy.

\section{The recomposition of the tax system}

The paucity of evidence supporting the claim that devolution will produce growth is compounded by an analysis of the tax reforms, which have been reasoned through the Northern Powerhouse imagery, and their effects on UK growth patterns. As I will now demonstrate, this selection of tax policies 'lock in' the increasing retention of tax revenue by affluent cities who are already growing. This sets in place a path-dependency of resources being increasingly concentrated into the spatial zones which are already characterised by growth and wealth, at the expense of redistributing resources to those less affluent cities who are even more in need of capital for investment. This means that this type of devolution, when analysed at the macroeconomic level, entrenches an economic system which exacerbates both geographical and social inequalities.

The pre-existing tax and investment settlement is being re-worked in a variety of ways, but this discussion is focused on the two most prominent mechanisms of 'localising' tax revenue, which have been rationalised through appealing to the Northern Powerhouse imagery. The first is the 'Earn Back' policy innovation, introduced as part of the 'Devo Manc' deal to 'reward growth'. The second is concerns the new framework established of allocating and setting the levies for business rates.

'Earn-back', as it was termed in the 'Devo Manc' agreement, denotes the retention of the additional tax revenue (up to $£, 900$ million) produced by infrastructure investments sanctioned by the City Mayor, of which there will be an increasing number over time (GMCA, 2012). The tax income acquired through these growth-generating investments will form a 'revolving fund' to support future investments in the city (GMCA, 2012). The Manchester devolution deal describes this local boon as a way of 'incentivising and rewarding growth'.

Secondly, the allocation of business rates - a form of tax currently amounting to $£ 26$ billion per annum across the UK (Osborne, 2015b) - has also been reconfigured. Between 1990 and 2013, business rates were collected locally and then transferred to central government who would distribute to local areas in the form of grant; based upon a formula which attempted to make resources more equitable. However, the Local Government Finance Act 2012, and the 
regulations that followed, enabled local government to retain 'up to half' of business rate growth in their area (LGA, 2013). Osborne (2015b) justified this reform by stating that 'when local areas take steps to boost business growth in their area, they should see the benefit', which again spoke to the concept of 'rewarding growth'. In the March 2015 Budget speech, Osborne announced that schemes piloting 100 per cent retention of business rates on the tax revenue arising from new businesses or the expansion of existing business would take place in 'Manchester and East Cheshire' and - that other central hub of the Northern Powerhouse - 'Cambridgeshire and Peterborough' (Osborne, 2015a). Soon afterwards, it was announced that all local authorities from 2020 will retain 100 per cent of business rates arising from new businesses or the expansion of existing business. This means that Revenue Support Grants (the mechanism of redistributing business rates) will be entirely phased out over the course of the current Parliament, although there will be a safety net for any council who loses 7.5 per cent of their business rates revenue in a year in order to 'ease' the transition.

That this retention relates only to the tax revenue arising from new businesses or the expansion of existing business means that this again represents an incremental and politically subtle change in governmental financing over time. However, as the size of the economy expands in size in forthcoming decades this modification will again act as a mode of concentrating national resources in those areas which are growing.

It is clear why this would appeal at the local level to policy-makers. The prospect of 'keeping' more of 'their' money is clearly a seductive proposition. Those cities who are currently contributing less to central government coffers than they are claiming back, however, need to be wary of this UK-wide trend of localising tax revenue. This direction of with the 'rewarding growth' parlance already being deployed in the more affluent parts of the country (Core Cities, 2013), means cities who are running 'budget deficits' with central government will suffer from the localisation of taxation. The winners and losers of business rates being localised can be projected through reference to the graph below.

\section{[ENTER FIGURE 2 HERE]}

Source: Data taken from O’Brien and Pike (2015)

As the graph demonstrates, London is set to be the biggest winner. Greater London (GLA) business rate revenue per worker is also, by far, the highest in the country, currently totalling $£ 1,420$ (Centre for Cities, 2015a).

Figure 3 shows overall tax surpluses and deficits amongst the regions of the UK. The effects of the localisation of tax revenue on the pan-Northern area - both through business rates being entirely retained locally or from the 'scaling up' of policy innovations such as 'Earn-Back' - can be deducted using the graph below. 
[ENTER FIGURE 3 HERE]

Source: City of London Corporation (2014: 55)

The retention of taxation is important not least because this constitutes capital which is available to re-invested in the local economy. This concentration of resources in a handful of UK cities, therefore, is only going to accelerate the geographical inequality in the UK.

The state's existing mechanisms of redistributing capital from the affluent to the poorer areas of the country, in order to tackle uneven development, would be diminished through such a recomposition of the tax and investment settlement. It would seemingly constitute a reconfiguration of the governmental allocation of resources which would primarily benefit the most affluent local areas and penalise the poorer areas that are desperately in need of capital for investment. In short, governmental capital would increasingly be allocated in London. That this re-scaling of the state's tax and investment financing is being rationalised through the Northern Powerhouse discourse therefore seems to be extremely disingenuous. 
Figure 4: City-Regions that generate the most business rates per worker $(2013 / 14)$

\begin{tabular}{|r|l|r|}
\hline \multicolumn{2}{|l|}{} & Business Rate revenue per worker (£) \\
\hline 1 & Greater London Area & 1,420 \\
\hline 2 & Glasgow and Clyde Valley City-Region & 1,160 \\
\hline 3 & Edinburgh City-Region & 1,037 \\
\hline 4 & Thames Valley Berkshire LEP & 998 \\
\hline 5 & Tess Valley PCA & 923 \\
\hline 6 & Humber PCA & 909 \\
\hline 7 & Aberdeen City-Region & 901 \\
\hline 8 & South East LEP & 899 \\
\hline 9 & GCGP LEP & 893 \\
\hline 10 & Enterprise M3 LEP & 888 \\
\hline
\end{tabular}

Source: Centre for Cities

To compound matters, to ensure that cities will remain fiscally sustainable - as if maintain the State's mechanisms of geographical redistribution were itself inherently unsustainable - Tax Increment Financing will also be set against the projection of future business rates in that polity. This institutional reform to the tax settlement again institutionalises an unequal set of parameters in which local authorities can operate, and enforces the inability for any 'disproportionate' Keynesian-style investment spending in less affluent cities in order to 'catch up' to the South. All of this amplifies the imbalances in available capital for investment.

There are of course more imbrications to the tax settlement not addressed here; income tax and corporation tax being obvious examples, which still represent crucial modes of redistribution. Undoubtedly, some vital governmental mechanisms of geographical and social redistribution would remain in place. However, several regressive modes of governmental distribution simultaneously remain in place and depoliticised. The most patent example of which is the disproportionate taxpayer-funded expenditure on London transport as opposed to elsewhere; with IPPR (2015: 5) reporting that expenditure per head was 2,604 in London compared to $f^{3} 314$ in the North East.

\section{Re-scaling the notion of 'dependency culture'}

The effects of the localisation of tax income on poorer areas have been acknowledged by some groups, who have responded by framing the issue in terms of 'breaking' the 'cycle of dependency' in which some cities are 'trapped'. Scaling up the 'cycle of dependency' theory often used by Ian Duncan's Smith Centre for Social Justice $(2007 ; 2013$; 2014) to refer to families who claim welfare benefits, organisations such as Respublica have argued that those cities currently running 'budget deficits' with central government will benefit from these reforms as it will force them to 
renounce the 'umbilical cord' of the state. A Respublica report on 'Devo Manc' argued that "high levels of public funding and low tax yields, are constraining the potential for Greater Manchester to be self-sustaining. Despite significant cuts to some public services over the past few years, total public spending in Greater Manchester has remained largely the same in real terms since 2008 , being $f^{22.5}$ billion in $2012 / 13$. This compares with an estimated total tax take of around $£ 17.7$ billion. Greater Manchester is currently a 'cost centre' for the UK, unable to reduce dependency or close the gap - of nearly $f, 5$ billion over a single year - between the taxes it generates and the cost of public services" (Blond and Morrin, 2014: 5). Such a statement illustrates the inclination of some to see devolution as a means of removing 'cost centres' from the teat of London. The report goes on to say that "to support genuine local decision making, we do believe measures will be needed to retain and manage tax resources generated locally - for example the local management and retention of income tax. As an operative principle which we term 'proportionate parity' we would argue that some of the freedoms enjoyed by the devolved nations should be enjoyed by city regions... In regard to Greater Manchester, we believe that once full placed based devolution of public services has taken place, fiscal devolution should follow" (Blond and Morrin, 2014: 6). This imagery of 'unsustainable' and 'dependent' cities has been echoed by many local government actors and even in a 'statement of evidence' to the London Finance Commission by Manchester City Council (2014).

Therefore, the financial implications of this prospective concentration of capital in affluent cities has been acknowledged in some form, but it has been framed in terms of 'reducing dependency', 'unsustainable' city financing, 'self-reliance' and 'incentivising' poor performing cities to grow; a language with contestable ideological and empirical underpinnings.

This new framework of taxation ensures an incremental, and politically subtle, means of 'locking in' the concentration of resources in those geographical areas which are already experiencing economic growth. These resources will form the funds for re-investing in those cities. All of this will mean that governmental resources will increasingly be funnelled, not into tackling uneven development through geographical redistribution, but into the continued success of the country's 'engines of growth'. This will ultimately exacerbate inequality in the UK, and it will be the less affluent areas of the country - much of which are in the North of England where this Powerhouse is supposedly being created - which will suffer the most. This reinforces, rather than rebalances, the UK economy through withdrawing the 'spatio-temporal fixes' of governmental redistribution which were designed to accommodate the political imperative of tackling uneven development from within the confines of a growth strategy centred upon the South East.

\section{Discussion: A race to the bottom}

Moreover, recent reforms to the business rate tax system - again justified through invoking the imagery of the Northern Powerhouse (Osborne, 2015b) - threaten to instigate a 'race to the bottom' between local authorities and city regions. George Osborne's abolition of universal business rates across all councils - with councils being authorised to reduce local business rates, but only raise them temporarily and under specific conditions as long as they 'win the support of 
local business' (Osborne, 2015b) - can be seen as the symbolic moment in which this 'race to the bottom' was inaugurated.

The institutionalisation of this rules-based framework can be understood as a form of statecraft which encourages local areas to offer more attractive business environments than their neighbours through the delivery of low local business rates and a lax approach to regulation. In so doing, there is a danger that devolution will further the structural conditions under which mobile capital is able to play polities off against each in order to seek out ever lower tax and regulation zones; or rather, that policy-makers could use such a rationale to rationalise such a policy approach.

Whilst business rates were kept at a uniform level across the country, inter-territorial competition for industry could be seen as a 'zero-sum' game at the national level (Cheshire and Gordon, 1998), but the announcement on business rates at the Conservative party Conference on October $5^{\text {th }} 2015$ enabled a far more deleterious form of Darwinian competition between subnational economic zones which will surely reduce the overall UK 'tax take' (Meadway, 2015).

Once again, framed by George Osborne as a form of empowerment and autonomy, the losers of this reform will be the ones who are less able or less willing (perhaps because of a predisposition towards progressive politics) to engage in tax competition. It is the poorer areas who will be least capable and most averse to the notion of reducing the rates, particularly in the context of cuts to their spending being imposed by central government. The more affluent areas on the other hand - who have suffered far less through the type of fiscal consolidation adopted since 2010 (Berry and White, 2014) - will be far more able to lower their rates. Unfortunately, any resistance to the dogma of competition is likely to help create the 'uneven playing field' of the UK economy. Thus, the institutional architecture has been put in place to facilitate a transforming topology of taxation and regulation across the UK economy in future years, with deleterious consequences for the poorest regions in the North for whom Osborne purports to be helping 'empower'.

The granting of additional powers of tax reform, within a rules-based framework which imposes strict conditions on raising any taxes such as gaining the consent of the Local Enterprise Partnership, sets the economic environment for competition between polities - designed to stimulate sites of 'urban entrepreneurialism' (Harvey, 1989: 4) - which conforms to a neoliberal understanding of inducing greater economic performance. It is no coincidence that the CBI's John Cridland believes that this reform to business rates is "putting flesh on the bones of the chancellor's commitment to devolution" (Cridland, 2015). In this sense, the reform of this tax system can be seen as a vehicle for unleashing a further neoliberalisation of the UK economy and a further institutional barrier to engendering a more progressive variety of political economy. In the end, any growth that is inspired by these changes is likely to be situated in those areas which will be the big winners of the aforementioned economic re-structuring rather than in those poorer areas of the countries who Osborne is keen to 'incentivise' out of their current economic malaise.

This recomposition of the tax settlement is a political expression of a certain understanding of wealth creation. It's an understanding partly based on the belief in low taxation and deregulation unleashing private enterprise, and inter-territorial competition in order to promote it. It is partly 
an understanding based on the emerging theory of agglomeration - the idea that increased productivity and growth is the result of business clustering because of economies of scale and networking effects - and the belief that maximising economic growth is best served through redirecting governmental resources to cities which are the likely locomotives of growth (Florida, 2002; Rosenthal and Strange, 2004; Glaeser, 2011; Overman, 2012; Champion and Townsend, 2013; Katz and Bradley, 2014). It is a theory which Peck situates within neoclassical economics (Peck, 2016) and which underpins recent reforms through the promise of maximising the 'returns' on governmental expenditure. The ascension of this theory echoes the increasing parochialism of 'economic development' at the current time. Capital is no longer being redirected to those areas most badly in need of investment, but to those areas which are already affluent but are likely to polish the aggregated national GDP figure.

It may well be that these City Deals produce higher growth in some areas of the country, but it is unlikely to occur in the North; a crucial point which speaks to the research of Pike et al. (2010) into the uneven geographies of the economic dividend. For once this recomposition of taxation is complete, devolution will profit London more than it will anywhere else. Additional capital will be channelled into those areas which are seen as being capable of driving growth, which are indeed the areas already experiencing it. This allocation then marks a political desire to maximise growth, wherever it is possible, regardless of how much that growth will be concentrated in the hands of those regions who need it the least (Layard, 2005; Wilkinson and Pickett, 2009), rather than address the challenges of uneven development through geographical redistribution. Indeed, the vast majority of the North which currently contributes less to Central Government coffers than they withdraw, will suffer from this localisation of tax revenue and will experience a further tightening of resources to compound the imposition of austerity.

That these reforms have been reasoned through the Northern Powerhouse imagery is extremely disingenuous; a point which again chimes with the analysis of Pike et al. (2010) who stated that the "advancement of the interests of an already prosperous albeit highly unequal region sits uneasily with the ways in which the economic dividend of devolution was promoted as a means to address the economic deficit and to ameliorate the marked spatial disparities between the nations and regions within the UK" (Pike et al., 2010: 26).

All of which means that the re-allocation of governmental resources justified by the Northern Powerhouse concept is likely to have rather severe, regressive implications for the less affluent areas of the country. This recomposition of taxation is set to blunt the State's mechanisms of redistribution and entrench uneven development by stymying the flow of available governmental capital to the under-developed areas.

\section{Conclusion}

An empirical analysis of the devolution discourse demonstrates its strong economic overtones. The proponents of devolution are confidently proclaiming that City Deals will bring with them an economic bounty which will help address economic inequality in the UK and substantiate George Osborne's Northern Powerhouse. An analysis of the recomposition of the tax state, however, reveals that the reforms reasoned under the guise of the Northern Powerhouse imagery, 
may have stark implications for regional economies within the UK. The localisation of taxation enacted by the re-scaling of the tax state once complete seems to suggest the bifurcation of local winners and losers within the UK, with the areas in the North set to experience a tightening of governmental expenditure which compounds the imposition of existing austerity measures. This point feeds into the analysis of Charlie Jeffery who, when writing on the topic of economic dividend, argued that "there is much to suggest that devolution - even administrative devolution in England - will lead to a widening of regional economic disparities, and that there is only a limited capacity on the part of UK government to intervene to secure UK wide economic balance" (Jeffery 2006: 1).

It appears, therefore, that the tax reforms rationalised by the Northern Powerhouse will primarily benefit London and the affluent areas of the South East, through enabling a greater retention of local profits and the institutionalisation of tax competition for which they are better position to engage in. For the North, they will - to use the controversial language of Philip Blond's Respublica - be 'liberated' from their debilitating 'dependency' on Central Government and those affluent areas who support them through the State's existing mechanisms of redistribution. It is difficult to decipher the dynamics on which growth in the North will be based, or where the investment to instigate such growth will emerge from.

These reforms can be understood as a political expression of a certain understanding of wealth creation. This understanding centres upon two beliefs. The first is that lower taxation on businesses, engendered through the encouragement of inter-territorial competition on taxation in this instance, is central to inspiring growth and space of 'urban entrepreneurialism'. The second is that cities are the locomotives of growth and, therefore, more governmental capital ought to be channelled into those spatial zones in order to accelerate the economic recovery. However, the increased retention of capital in 'budget surplus' cities such as London, and stymying the redistribution of this capital to the North more pertinently, seems to be a driven by a political privileging of accelerating aggregate national growth anywhere it can be eked out rather than addressing uneven development.

Tackling uneven development remains a monumental task, but depends heavily on a strong industrial policy coordinated by the State which stimulates alternative industries in the North. This was a point implicitly acknowledged in the 'economic rebalancing' agenda prevalent between 2010 and 2012; the failure of which may have catalysed the devolution discourse of 'prosperity through local agency' in the speeches of Conservative Party front-benchers. Yet it remains the case that devolution is unable in isolation to challenge the dominance of the UK's finance-led growth strategy or the peripheralisation of certain industries and regions within that. In this sense, this article dovetails with the work of Pike et al. (2010:11) who argued that the economic dividend "remains difficult to discern because its likely effects are over-ridden by the role of national economic growth in decisively shaping the pattern of spatial disparities and in determining the scope and effects of spatial economic policy and decentralisation".

It would be tragically ironic if devolution were to actually exacerbate geographic and social inequalities, as the devolution agenda has partly gained such political momentum through the perceived need to tackle inequality and uneven development. It does however seem to be the case that the Northern Powerhouse agenda has been co-opted as vehicle for promoting policies 
that engender a more regressive political economy settlement; disguised by a discourse of empowerment, localism and autonomy.

\section{References}

Ashcroft B, Swales JK and McGregor PG (2005) Is devolution good for the Scottish economy? A framework for analysis. Devolution Briefings 26, March, ESRC Devolution and Constitutional Change Programme, Available at: http://www.devolution.ac.uk/Briefing_papers.htm

Bailey D (2015) Osborne's Northern Powerhouse centralises power and devolves blame. Centre for Labour and Social Studies, November $5^{\text {th }}$ 2015. Available at: http:// classonline.org.uk/blog/item/tory-devolution-localising-accountability-and-deliverywhilst-shoring-up-th

Baskaran T and Feld LP (2009) Fiscal Decentralization and Economic Growth in OECD Countries: Is There a Relationship? CESifo Working Paper Series No. 2721. Available at SSRN: http:/ / ssrn.com/abstract $=1441152$

Berry C (2013) Are we there yet? Growth, rebalancing and the pseudo-recovery. SPERI Paper 7, Available at:

http://speri.dept.shef.ac.uk/wp-content/uploads/2013/01/SPERI-Paper-No.7-Are-We-ThereYet-PDF-747KB.pdf

Berry C and Hay C (2014) 'The Great British 'Rebalancing' Act: The Construction and Implementation of an Economic Imperative for Exceptional Times. British Journal of Politics and International Relations, doi: 10.1111/1467-856X.12063

Berry C and White L (2014) Local authority spending cuts and the 2014 English Local Elections. Speri Brief 6, July 2014. Available at: http://speri.dept.shef.ac.uk/wpcontent/uploads/2014/07/Brief6-local-authority-spending-cuts.pdf

Blond P and Morrin M (2014) Devo max - Devo Manc: Place-based public services. Respublica, September 2014, available at: http://www.respublica.org.uk/wp-content/uploads/2014/10/csvDevo-Max-Report.pdf

Blond P and Morrin M (2015) Restoring Britain's City States. Respublica, February 2015. Available at: $\quad$ http://www.respublica.org.uk/wp-content/uploads/2015/02/Restoring-Britains-CityStates.pdf 
Buigues P-A and Sekkat K (2009) Industrial Policy in Europe, Japan and the United States: Amounts, Mechanisms and Effectiveness. Basingstoke: Palgrave Macmillan.

Centre for Cities (2015a) Mapping Britain's public finances: Where is tax raised, and where is it spent? July $6^{\text {th }} 2015$. Available at: http://www.centreforcities.org/publication/mapping-britainspublic-finances-where-is-tax-raised-and-where-is-it-spent/

Centre for Cities (2015b) What are the key economic questions for Sadiq Khan to answer in London Mayoral bid? September 11 ${ }^{\text {th }}$ 2015. Available at: http://www.centreforcities.org/blog/what-are-the-key-economic-questions-for-sadiq-khan-toanswer-in-london-mayoral-bid/

Centre for Social Justice (2007) Breakthrough Britain: Economic Dependency and Worklessness. July $10^{\text {th }} 2007 . \quad$ Available at: http://www.centreforsocialjustice.org.uk/publications/breakthrough-britain-economicdependency-and-worklessness (accessed on September 17 2015).

Centre for Social Justice (2013) Up to the Job? How reforming Jobcentre Plus will tackle worklessness. July 2013. Available at: http://www.centreforsocialjustice.org.uk/publications/upto-the-job-how-reforming-jobcentre-plus-will-tackle-worklessness (accessed on September 17 2015).

Centre for Social Justice (2014) The Journey to Work: Welfare reform for the next Parliament. June 2014. Available at: http://www.centreforsocialjustice.org.uk/publications/the-journey-towork-welfare-reform-for-the-next-parliament (accessed on September 17 2015).

Champion T and Townsend A (2013) Great Britain's second-order city regions in recessions. Environment and Planning A 45(2): 362-382.

Cheshire PC and Gordon I (1998) Territorial competition: some lessons for policy. Annals of Regional Science 32: 321-346.

City of London Corporation (2014) London's Finances and Revenues. November 2014. Available at: https://www.cityoflondon.gov.uk/business/economic-research-andinformation/research-publications/Documents/Research2014/londons $\% 20$ finance $\% 20$ and $\% 20$ revenues.pdf

Core Cities (2013) Unlocking urban economies through devolution. Core Cities Group, London. 
Cridland J (2015) Q\&A: Unpicking Osborne’s Business Rate Reform. The Financial Times. Jim Pickard, Andy Bounds and Kate Allen. October $6^{\text {th }}$ 2015. Available at: http://www.ft.com/cms/s/0/e866ac2a-6c31-11e5-aca9-d87542bf8673.html\#axzz3nudxeknS

Crouch C (2009) Privatised Keynesianism: An Unacknowledged Policy Regime. British Journal of Politics and International Relations 11(3): 382-99.

Department for Communities and Local Government [DCLG] (2015) “Devolution plans for London scrutinised" Commons Select Committee, 19 November 2015. Available at: http://www.parliament.uk/business/committees/committees-a-z/commonsselect/communities-and-local-government-committee/news-parliament-2015/devolution-billevidence-15-16/

Florida R (2002) The rise of the creative class: and how it's transforming work, leisure, community and everyday life. New York: Basic Books.

Glaeser EL (2011) Triumph of the City. London: Macmillan.

Greater Manchester Combined Authority [GMCA] (2012) Greater Manchester City Deal. Available at www.agma.gov.uk/cms_media/files/city_deal_final_text_210312.doc (accessed on September 5 2015).

Harvey D (1989) From managerialism to entrepreneurialism: the transformation in urban governance in late capitalism. Geografiska Annaler. Series B. Human Geography, 3-17.

Hay C (2013) The failure of Anglo-Liberal Capitalism. London: Palgrave.

Heseltine M (2012) No Stone Unturned: In pursuit of growth. London: Department for Business, Innovation and Skills.

Hildreth P and Bailey D (2013) The economics behind the move to 'localism' in England. Cambridge Journal of Regions, Economy and Society 6(2): 233-249

HM Treasury and GMCA (2015) Greater Manchester Agreement: devolution to the GMCA and transition to a directly elected mayor. London: Stationary Office.

Institute for Public Policy Research [IPPR] (2015). Rhetoric to Reality: A business agenda for the Northern Powerhouse. Ed Cox and Luke Raikes, September 2015. Available at: http://www.ippr.org/files/publications/pdf/rhetoric-to-reality-sep2015.pdf?noredirect=1 
Ipsos Mori (2015) Public knows little about the 'devolution revolution' - but supports local decision-making. Available at: https://www.ipsosmori.com/researchpublications/researcharchive/3645/Public-knows-little-about-thedevolution-revolution-but-supports-local-decisionmaking.aspx (accessed on November 5 2015). Jeffery C (2006) Final Report of the Devolution and Constitutional Change Programme. School of Social and Political Studies: University of Edinburgh.

Katz B and Bradley J (2014) The Metropolitan Revolution: How Cities and Metros are Fixing Our Broken Politics and Fragile Economy. Washington, DC: Brookings Institution.

Layard R (2005) Happiness. London: Allen Lane.

Lee S (2015) Law, Legislation and Rent Seeking: The role of the Treasury-led Developmental State in The Competitive Advantage of The Southern Powerhouse. Presentation at the Political Economy of the Northern Powerhouse workshop, Sheffield, November 12th 2015.

Local Government Association [LGA] (2013) Rewiring Public Services: Business Rate retention. December 2013. Available at: http://www.local.gov.uk/documents/10180/11531/The+story+so+far++business + rate+ retention.pdf/2175c47c-6916-4b93-add8-c2201db60482

London Assembly (2013) London and England's largest cities join to call for greater devolution to drive economic growth. September 30 ${ }^{\text {th }}$ 2013. Available at: http://www.london.gov.uk/media/mayor-press-releases/2013/09/london-and-englands-largestcities-join-to-call-for-greater

London Finance Commission (2013) Raising the Capital, May 2013, https://www.london.gov.uk/what-we-do/business-and-economy/promoting-london/londonfinance-commission

Lyall S, Wood M and Bailey D (2015) Democracy: The missing link in the devolution debate. New Economics Foundation, December $3^{\text {rd }}$ 2013. Available at: http://www.neweconomics.org/publications/entry/democracy-the-missing-link-in-thedevolution-debate

Maclennen D and O'Sullivan A (2013) Localism, devolution and housing policies. Housing Studies 28(4): 599-615. 
Manchester City Council (2014) Statement of evidence to the London Finance Commission. Available at: https://www.london.gov.uk/sites/default/files/Manchester.pdf (accessed 15 July 2015).

McGregor PG and Swales K (2005) Economics of devolution/decentralization in the UK: Some questions and answers. Regional Studies 39(4): 477-494.

Meadway J (2015) A growing gap in the Chancellor's long-term economic plan. New Economics Foundation, October $28^{\text {th }}$ 2015. Available at: http://www.neweconomics.org/blog/entry/agrowing-gap-in-the-chancellors-long-term-economic-plan

Morgan KJ (2002) The New Regeneration Narrative: Local Economic Development in the Multi-Level Polity. Local Economy 17(3): 191-199.

National Audit Office [NAO] (2015) A Short Guide to the Department for Communities and Local Government. July 2015 Available at: https://www.nao.org.uk/wpcontent/uploads/2015/08/A-Short-Guide-to-the-Department-for-Communities-and-Local-

Government.pdf

O'Brien P and Pike A (2015) City Deals, decentralisation and the governance of local infrastructure funding and financing in the UK. National Institute of Economic and Social Research, 233(1): 14-26.

Osborne G (2015a) Chancellor George Osborne's Budget 2015 speech. Speech given on March 18 2015. Transcribed by HM Treasury. Available at: https://www.gov.uk/government/speeches/chancellor-george-osbornes-budget-2015-speech Osborne G (2015b) Chancellor unveils ‘devolution revolution'. HM Treasury, October $5^{\text {th }} 2015$. Available at: https://www.gov.uk/government/news/chancellor-unveils-devolution-revolution Overman HG (2012) Investing in the UK's most successful cities is the surest recipe for national growth. British Politics and Policy at LSE (26 Jan 2012). Available at: http://eprints.lse.ac.uk/44073/

Peck J (2016) "Economic Rationality meets Celebrity Urbanology", International Journal of Urban and Regional Research, DOI: 10.1111/1468-2427.12321 
Pike A and Tomaney J (2009) The state and uneven development: the governance of economic development in England in the post-devolution UK. Cambridge Journal of Regions, Economy and Society. http://cjres.oxfordjournals.org/content/early/2009/01/29/cjres.rsn025.short

Pike A, Rodríguez-Pose A, Tomaney J, Torrisi G, and Tselios V (2010) In search of the 'economic dividend' of devolution: spatial disparities, spatial economic policy and decentralisation in the UK. SERC Discussion Papers, SERCDP0062. Spatial Economics Research Centre (SERC). London: London School of Economics and Political Sciences.

Rodríguez-Pose A and Ezcurra R (2010) Is Fiscal Decentralisation harmful for economic growth? Evidence from the OECD countries. Journal of Economic Geography 11(4): 619-643.

Rodríguez-Pose A and Gill N (2005) On the 'economic dividend' of devolution. Regional Studies 39(4): 405-420.

Rodríguez-Pose A and Sandall R (2008) From identity to the economy: Analysing the evolution of the decentralisation discourse. Environment and Planning C: Government and Policy 26(1): 54-72.

Rosenthal SS and Strange WC (2004) Evidence on the nature and sources of agglomeration economies. In: V Henderson, J-F Thisse (eds) Handbook of Regional and Urban Economics: Vol 4. Amsterdam: Elsevier, pp: 2119-2171.

Smith MJ and Richards D (2015) Devolution in England, the British political tradition and the absence of consultation, consensus and consideration. Representations, 51(4): 1-18.

The London Standard (2012) 'Give London back its tax': Boris Johnson demands return on cash that capital makes for Britain. April $4^{\text {th }}$ 2012. Available at: http://www.standard.co.uk/news/mayor/give-london-back-its-tax-boris-johnson-demandsreturn-on-cash-that-capital-makes-for-britain-7618555.html

The London Standard (2015) Sadiq Khan: We must trust Londoners to run the capital. August $26^{\text {th }}$ 2015. Available at: http://www.standard.co.uk/comment/sadiq-khan-we-must-trustlondoners-to-run-the-capital-9691016.html

Tomaney J (2016) Limits of Devolution: Localism, Economics and Post-democracy. The Political Quarterly, DOI: 10.1111/1467-923X.12280

Wilkinson R and Pickett K (2009) The Spirit Level: Why More Equal Societies Almost Always Do Better. London: Penguin Publishing. 
Williams N, Brooks C and Vorley T (2016) Hidden clusters: the articulation of agglomeration in City Regions. Environment and Planning C, DOI: 10.1177/0263774X16642229 